\title{
THE ROLE OF PEPSINOGENES AND SOME INTESTINAL HORMONES IN PATHOGENESIS OF GASTROESOPHAGEAL REFLUX DISEASE
}

\author{
Vira Boichuk \\ Department of general practice (family medicine), physical rehabilitation and sports medicine \\ Ivano-Frankivsk National Medical University \\ 2 Halytska str., Ivano-Frankivsk, Ukraine, 76018 \\ viraboychuk@yahoo.com
}

\begin{abstract}
80 patients with gastroesophageal reflux disease (GERD) were examined. The diagnosis of GERD was based on the history of the disease, complaints of patients, the results of daily monitoring of $\mathrm{pH}$ in the lower third of the esophagus, data of fibroesophagogastroduodenoscopy, chromoendoscopy, 13C-octanoic breath test, gastrin-17 (G-17) concentration, pepsinogens I and II (P I and II) and cholecystokinin-pancreozymin (C-P) in serum.

After 24 hours $\mathrm{pH}$ monitoring of the lower third of the esophagus in 40 patients with GERD, the predominance of acid was found, and the other 40 patients had mixed refluxes. In patients with predominance of acid reflux, the mean values of half-life of solid food evaluation (T1/2) according to $13 \mathrm{C}$-octanoic breath test was $(45.25 \pm 1.34) \mathrm{min}$. With the predominance of mixed refluxes in patients, there was a tendency towards hypokinetic motility of the stomach, indicating a slowdown in half-life of solid food evaluation from the stomach up to $(139.24 \pm 11.87) \mathrm{min}$. With the predominance of acid reflux also was observed a significant reduction in the concentration of G-17 and C-P, an increase in P I and a decrease in the concentration of P II. Hypergastrinemia, high levels of C-P and P II $(37.44 \pm 3.41) \mu \mathrm{g} / 1(\mathrm{p}<0,05)$ were diagnosed with the predominance of mixed refluxes.

Keywords: gastroesophageal reflux disease, 24 hours $\mathrm{pH}$ monitoring of the lower third of the esophagus, 13C-octanoic breath test, gastropanel, cholecystokinin-pancreozymin.
\end{abstract}

\section{Introduction}

Gastroesophageal reflux disease (GERD) is a multifactorial disease, the occurrence of which is important as a contributing factor, among which stress, work associated with inclining, obesity, smoking, some medication, nutrition, and determinative factors, which include cardiac failure, reflux of gastric and duodenal contents, decreased esophageal clearance and resistance of the mucous membrane of the esophagus $[1,2]$.

A significant number of exogenous and endogenous factors influences the tonus of the lower esophageal sphincter $[3,4]$. In particular, the pressure in it decreases under the influence of a number of gastrointestinal hormones: glucagon, gastrin, somatostatin, cholecystokinin, secretin, vasointestinal peptide, enkephalin $[5,6]$. Reducing the tonus of the lower esophageal sphincter may also be due to a violation of receptor sensitivity to gastrin, both at the periphery and in the central nervous system [7, 8]. Due to the violation of regulatory mechanisms that coordinate the periodic motor activity of the gastrointestinal tract, there is a disintegration of the secondary peristalsis of the esophagus, dysfunction of the lower esophagus and pyloric sphincter, increasement of intragastric and intraduodenal pressure [9].

\section{Aim of research}

To study the nature of changes in the motor-evacuation function of the stomach and indicators of 24 hours $\mathrm{pH}$ monitoring in the lower third of the esophagus, to establish the role of gastrin-17, cholecystokinin- pancreozymin, changes in the level of pepsinogens and their correlation in the pathogenesis of gastroesophageal reflux disease.

\section{Materials and methods}

The work was performed at the Department of general practice (Family medicine), physical rehabilitation and sports medicine of the Ivano-Frankivsk National Medical University, for the period 2014-2016. 80 patients with GERD were examined. The age of the patients varied from 
19 to 73 years and amounted to an average of $45.88 \pm 1.32$ years, the mean duration of GERD was $6.67 \pm 1.07$ years.

The main verifying method in the diagnosis of GERD is fibroesophagogastroduodenoscopy (FEGD) according to the generally accepted method using the "Olympus" apparatus GIF-XPE. In establishing the clinical diagnosis of GERD, the degree of damage to the esophagus was determined after an endoscopic examination (A, B, C, D), according to the Los Angeles classification [10]. Among the additional endoscopic diagnostic methods, the most accessible and informative was the chromoscopy with the use of dye (Lugol solution) [11].

The statistical processing of the obtained results was carried out using the software - Microsoft Excel spreadsheet and application package Statistica v. 10.0 StatSoft, USA. Estimation of the probability of divergence of mean values of the conducts using the dual t-criterion of Student.

\section{Experimental procedures}

Daily (24-hour) esophageal $\mathrm{pH}$. The method allowed to quantify the frequency, duration and daily dynamics of gastroesophageal and gastroduodenal reflux, the number and duration of episodes of $\mathrm{pH}<4$ and $>7$ in the esophagus. Lower esophageal $\mathrm{pH}$ monitoring in the night and day periods was performed by acidogastrograph AG-1rN-M. The night period was determined from the time when the patient lay in bed to fall asleep until the morning when he woke up. In the analysis of daily monitoring of $\mathrm{pH}$ in the lower third of the esophagus, we evaluated the measurements of the DeMeester scale.

The motor-evacuation function of the stomach was examined using the ${ }^{13} \mathrm{C}$-octanoic breath test. The air analysis was carried out on IRIS (Wagner-Analysen-Technic, Germany) infrared analyser. A concentration curve of ${ }^{13} \mathrm{CO}_{2}$ was constructed and the half-life of solid food from the stomach in minutes $\left(\mathrm{T}_{1 / 2}\right)$ and the drainage factor (GEC) were calculated.

Research of the concentration of gastrin, pepsinogen I and II in the blood was carried out on the basis of the GasroPanelBIOHIT (Finland) test system. The basis of the technology of the panel "GasroPanel" is the principle of enzyme-linked immunosorbent assay (ELISA). The special ELISA equipment of the company "VIONIT" allowed to measure the level of pepsinogens I and II, gastrin-17. Investigation of the concentration of cholecystokinin-pancreozymin in serum was performed by the enzyme-linked immunosorbent method, using "Peninsula Laboratories Inc" (USA) and expressed in $\mathrm{ng} / \mathrm{ml}$.

\section{Results}

Young patients (16-29 years of age) were more likely to have an A-B degree of esophagitis than C-D $\left(\chi^{2}=2.571 ; p>0.05\right)$, while people over 60 years of age were more likely to have a degree of $\mathrm{C}-\mathrm{D}$ (in 3 out of 5 cases; $\chi^{2}=0.171 ; \mathrm{p}>0.05$ ). At the age of $30-59$, B than A, C and D was significantly more likely to be diagnosed $\left(\chi^{2}=6.332 ; \mathrm{p}<0.05 ; \chi^{2}=3.741 ; \mathrm{p}>0.05 ; \chi^{2}=12.692 ; \mathrm{p}<0.001\right)$. At the duration of GERD $1-5$ years, the stages A $(10.00 \%)$ and B $(5.00 \%)-\chi^{2}=4.000$ were significantly more often diagnosed; $\mathrm{p}<0.05$. At the duration of the disease up to 10 years, a tendency towards the progression of the esophagitis is noted: stage $\mathrm{B}$ is diagnosed at $22,50 \%$, and $\mathrm{C}-$ at $17,50 \%$, which has been significantly more developed in compared to the duration of the disease to 5 years $\left(\chi^{2}=10.329\right.$; $\mathrm{p}<0.01)$. In patients with a long history of GERD ( $>10$ years $)$, the stages of $\mathrm{C}-\mathrm{D}\left(\chi^{2}=8,526 ; \mathrm{p}<0.01\right)$ were significantly more often established.

Two cases of Barrett's esophagus were detected and histologically verified with the chromoeozofagoendoscopy. These patients were subsequently excluded from the study.

After 24-hours $\mathrm{pH}$ monitoring in the lower third of the esophagus in 40 patients with GERD, the predominance of acid was found, and in the other 40 patients were detected mixed refluxes.

The peculiarities of the daily $\mathrm{pH}$ analysis with the predominance of acid refluxes were: the mean value of the intra-esophageal $\mathrm{pH}(4.58 \pm 0.33)(\mathrm{pH}$ min $-\mathrm{pH}$ max, respectively, $1.64 \pm 0.23-6.45 \pm 0.52$ ), indicating about a stable acid aggression of the lower third of the esophagus. In $77.50 \%$ of patients, the persistent predominance of acid reflux with average values $(3.22 \pm 0.15)$ was established. At $15.00 \%$, respectively, the average values of the intravascular $\mathrm{pH}$ were $(4.78 \pm 0.36)$, and $7.50 \%-(7.08 \pm 0.42)$. The average time of throwing aggres- 
sive gastric juice was 1 hour per day $(77.24 \pm 5.14) \mathrm{min}$. The average number of acid episodes of $>5$ min was 57 .

Often, acidic refluxes were recorded in the first half of the night (7.28 \pm 0.64$)$. In the upright position of the body, the acidity of the lower third of the esophagus was observed during $(8.24 \pm 0.75) \mathrm{min}$, often these episodes of long-term acid reflux were observed after ingestion of fat or use of large portions of food. In patients with predominance of acid reflux, the DeMeester index was (28.78 \pm 0.18$)$ (normally up to 14.72 ).

With the predominance of mixed reflux in patients with GERD, the mean intra-invasive $\mathrm{pH}$ value with a tendency toward neutral indices $(5.69 \pm 0.29)$ was statistically significant $(\mathrm{p} 1<0.001)$. The variation of the minimum and maximum values of the esophagus $\mathrm{pH}$ was $(3.01 \pm 0.12)-$ (7.89 \pm 0.66$)$, respectively.

Such values are evidently due to the presence of duodenal and biliary content in the esophagus. Total daily time, when in the lower third of the esophagus, the $\mathrm{pH}<4.0$ was less than an hour $(44.84 \pm 2.07) \min \left(\mathrm{p}_{1}<0.01\right)$, however, the time of contact of the lower third of the esophagus with alkaline contents of the $\mathrm{pH}>7.0(75.25 \pm 0.61) \mathrm{min}\left(\mathrm{p}_{1}<0.001\right)$. The total DeMeester mean was $(18.87 \pm 0.09)\left(\mathrm{p}_{1}<0.01\right)$.

According to the results of the ${ }^{13} \mathrm{C}$-octanoic breath test in the examined patients, in the practically healthy people, the half-life of food $\left(\mathrm{T}_{1 / 2}\right)$ from the stomach was $(64.69 \pm 2.17) \mathrm{min}$, and the drainage factor (GEC) - (3.97 \pm 0.03$)$. In patients with predominance of acid reflux, according to daily monitoring of $\mathrm{pH}$ in the lower third of the esophagus, the mean values of the ${ }^{13} \mathrm{C}$-octanoic breath test were $\mathrm{T}_{1 / 2}-(45.25 \pm 1.34) \mathrm{min}, \mathrm{p}<0.05$ and GEC $(4.15 \pm 0.13, \mathrm{p}<0.05$, indicating the predominance of the hypermotor type of gastric contractility and excessively accelerated evacuation of food.

With the predominance of mixed refluxes in patients, there was a tendency toward hypokinetic motility of the stomach, indicating a slowdown $\mathrm{T}_{1 / 2}$ to $(139.24 \pm 11.87) \mathrm{min}$, as compared with healthy $(\mathrm{p}<0.05)$, and with patients in which determined the dominance of acid refluxes $\left(\mathrm{p}_{1}<0.05\right)$, and a significant decrease in GEC $-(2.12 \pm 0.19)\left(\mathrm{p}<0.05 ; \mathrm{p}_{1}<0.05\right)$.

All patients with GERD have been tested for the content of gastrin-17, cholecystokinin-pancreozymin, pepsinogen-I and pepsinogen-II [12]. They have a multidirectional change in hormonal secretion and motor-evacuation function of the lower part of the esophagus, stomach and sphincter apparatus.

With the predominance of acid reflux, a significant reduction in the concentration of T-17 with mean values $(4.28 \pm 0.21) \mathrm{pmol} / \mathrm{l}(\mathrm{p}<0.05)$ and C-P $(3.25 \pm 0.17) \mathrm{ng} / \mathrm{ml}(\mathrm{p}<0.05)$, a rise in P I to $(375.18 \pm 15.25) \mu \mathrm{g} / \mathrm{l}(\mathrm{p}<0.05)$, and a decrease in the concentration of P II to $(15.12 \pm 1.24) \mu \mathrm{g} / \mathrm{l}(\mathrm{p}>$ $0,05)$ and increase the ratio of P I/P II to $(22.83 \pm 1.89)$ of cond. units. Instead, with the predominance of mixed reflux, hypergastrinemia $(24.28 \pm 1.87) \mathrm{pmol} / \mathrm{l}(\mathrm{p}<0.05)$, high level of C-P $(7.27 \pm 0.42) \mathrm{ng} /$ $\mathrm{ml}(\mathrm{p}<0.05)$ and PII $(37.44 \pm 3.41) \mu \mathrm{g} / 1(\mathrm{p}<0.05)$. In these patients, the concentration of P I tended to decrease but did not significantly differ from healthy subjects $(112.27 \pm 8.74) \mu \mathrm{g} / \mathrm{l}(\mathrm{p}>0.05)$, although there was a significant decrease in the P I /P II ratio to $(5.57 \pm 0.47)$ of the cond. units $(\mathrm{p}<0.05)$.

\section{Discussion}

In patients with predominance of acid reflux, the accelerated evacuation of the stomach is likely to indicate a dyskinetic prolapse and propulsion through the lower diaphragmatic sphincter and the ingestion of aggressive acidic contents in the stomach.

In $70 \%$ of patients with GERD with predominance of acid reflux hypertonic-hyperkinetic type of motor-evacuation function of the stomach is noted. This is also evidenced by the presence of a direct strong correlation between $\mathrm{T}_{1 / 2}$ and the $\mathrm{pH}$ mean in the lower part of the esophagus $(\mathrm{r}=0.85 ; \mathrm{p}<0.001)$ and GEC $\mathrm{pH}(\mathrm{r}=0.79 ; \mathrm{p}<0.001)$. Normal kinetic and hypokinetic motility of the stomach was observed rarely. Therefore, it should be considered that in patients with a combination of hyperkinetic state of motility and prolonged acid reflux in the esophagus, the acid component itself plays a leading role in the progression of the disease, which causes the need for higher doses of antacids. Instead, according to the results of our own studies, it was found that in patients with frequent and prolonged alkaline reflux, the hypotonic-hypokinetic type (57.5\%) was characteristic, as evidenced by the presence of the average strength of a direct correlation between $T_{1 / 2}$ and the 
prevalence of alkaline esophagitis $\mathrm{pH}(\mathrm{r}=0.62 ; \mathrm{p}<0.01)$ and $\mathrm{GEC}$ and $\mathrm{pH}(\mathrm{r}=0.68 ; \mathrm{p}<0.01)$. Also, one out of five patients did not have a significant gastrointestinal motility disorder. In our opinion, structural changes in SOS are due to the damaging effects of the acidic component and the long stasis in the stomach and the remitting of retrograde duodenal contents containing bile acids. Therefore, before treatment in such patients, it is appropriate to attach a prokinetic drug and an agent that would neutralize the biliary component of the reflux.

After analysis of the correlation of blood T-17 concentration with the 24-hours $\mathrm{pH}$ monitoring of the lower part of the esophagus using the odds ratio method, it was found that in patients with low levels, acid reflux with $\mathrm{pH}$ ranged from 3.0 to $3.99(\mathrm{OR}=8.69 ; \mathrm{p}=0.04)$ and with $\mathrm{pH} 2.0-2.99$ $(\mathrm{OR}=7.43 ; \mathrm{p}=0.02)$ and somewhat less frequently from $\mathrm{pH} 1.0-1.99(\mathrm{OR}=3.0 ; \mathrm{p}=0.03)$. (not indicated in the presented article). Most often (23.4 2.4) cases in the lower third of the esophagus were recorded $\mathrm{pH}$ in the range of 2.0-2.99, less $(15.4 \pm 1.6)$ cases per day - with $\mathrm{pH} 3.0-3.99$. In patients with GERD in (8.9 \pm 1.9$)$ cases per day, reflux was found to be too acidic with $\mathrm{pH}$ in the range of 1.0-1.99. The alkaline reflux in patients with GERD with a low level of gastrin in serum is not registered.

In subjects with elevated level G-17, the results of daily monitoring of the $\mathrm{pH}$ of the lower third of the esophagus were more often recorded alkaline reflux with $\mathrm{pH}$ in the range of 7.0-7.99 $(\mathrm{OR}=2.6 ; \mathrm{p}=0.04)$, the total number of which was $(15.5 \pm 2.1)$ episodes per day $(\mathrm{p}<0.05)$, whereas at normal level of T-17 only in (2.3 \pm 0.4$)$ cases. Also in patients with GERD with high level of T-17 blood in $(6.2 \pm 1.1)$ cases in the lower third of the esophagus, the $\mathrm{pH}$ was determined in the range of 8.0-8.5, in the absence of episodes of such ingestion in patients with normal and lowered level G-17. This fact can be explained by the stimulating effect of gastrin on peristalsis of the gastrointestinal tract. G-17 induces secretin secretion, and C-P, consequently, enhances the secretion of bile and pancreatic secretion that is thrown into the stomach and esophagus. C-P also stimulates the secretion of the gastric secretion, suppresses its evacuation, and relaxes the Oddi sphincter.

After analysing the relationship between the level of T-17 in the blood, the duration of GERD, it was found that in patients with a long history of disease to one and from one to five years of age, its serum concentration did not differ and equalled, respectively $(5.41 \pm 1.12) \mathrm{pmol} / \mathrm{l}$ and $(7.33 \pm 1.40) \mathrm{pmol} / 1(\mathrm{p}>0.05)$. In $75.50 \%$ of patients with GERD with a history of the disease $>5$ years, the concentration of G-17 was $(20.55 \pm 3.10) \mathrm{pmol} / \mathrm{l}$, exceeding the indexes of the first duration of the disease by 3.8 and 2.8 times $\left(\mathrm{p}_{1,2}<0.05\right)$.

The emergence of pathological gastroesophageal reflux is largely dependent on the disturbed motility of the stomach and duodenum $[13,14]$, while the infection and eradication of Helicobacter Pylory do not play an important role in the genesis of GERD, which is also noted in the 4 Maastricht consensus. In addition, the discoordination of the motor-evacuator function of the upper parts of the gastrointestinal tract, in particular the stomach, is the basis for the appearance of mixed (duodenal refluxes), due to the imbalance in the contractile activity of the antral and pyloric divisions and the duodenum $[15,16]$. The rate of reduction of the stomach also depends on the level of some gastrointestinal hormones, in particular, ghrelin (a direct biochemical predictor of this process) and gastrin $[17,18]$. Reducing the tone of the stomach and slowing the evacuation period from it is often combined with the increased contractile capacity of the duodenum and the appearance of duodenogastric and gastroesophageal reflux and the development of GERD [19, 20]. In addition, there is a certain correlation between the appearance of such refluxes with the function of gastric receptors, especially as gastrin enhances motor function of the stomach.

\section{Conclusions}

1. In gastroesophageal reflux disease, A (23.75\%), B (37.50\%), and C (25.00\%) degrees of esophagitis, according to the Los Angeles Endoscopic Classification, were predominantly diagnosed.

2. According to 24-hours $\mathrm{pH}$ monitoring of the lower third of the esophagus, patients with gastroesophageal reflux disease with almost identical frequency recorded acid and mixed reflux. The number of episodes of acid regurgitation was 57 cases, the retention time of $\mathrm{pH}<4-$ (77.24 \pm 5.14 ) min per day. The frequency of reflux mixed with a $\mathrm{pH}>7$ was 9 cases, respectively, and their duration - (75.25 \pm 0.61$)$ min per day. 
3. In cases of prevalence of acidic esophageal reflux, an increase in contractional function of the stomach was observed with $\mathrm{T}_{1 / 2}(45.25 \pm 1.34) \mathrm{min}(\mathrm{p}<0.05)$, and in case of mixed reflux there was a slowed-down type of $\mathrm{T}_{1 / 2}(139.24 \pm 11.87) \min (\mathrm{p}<0,05)$.

4. In patients with gastroesophageal reflux disease with a low level of gastrin-17 in serum, acidic reflux was found to prevail from $\mathrm{pH} 3.00-3.99(\mathrm{OR}=8.69 ; \mathrm{p}=0.04), \mathrm{pH} 2.00-2.99(\mathrm{OR}=7.43$; $\mathrm{p}=0.02)$, and $\mathrm{pH} 1.00-1.99(\mathrm{OR}=3.0 ; \mathrm{p}=0.03)$, and for increasing its concentration, mixed reflux was recorded with $\mathrm{pH}$ at intervals of $7.00-7.99(\mathrm{OR}=2.6, \mathrm{p}=0.04)$.

5. In patients with gastroesophageal reflux disease, with the predominance of acid reflux, the concentration of pepsinogen I in the blood was 3.5 times higher than in healthy subjects, and the level of pepsinogen II did not differ from the norm with increasing their ratio, and with the predominance of mixed - the concentration of pepsingogen I in the blood was within the normal range with an increase in the level of pepsinogen II to $(37.44 \pm 3.41) \mu \mathrm{g} / \mathrm{l}$ and a decrease in their ratio to $(5.57 \pm 0.47)$ cond. unit.

\section{Acknowledgments}

Sincerely gratitude to the Department of general practice (Family medicine), physical rehabilitation and sports medicine of the Ivano-Frankivsk National Medical University and to the employees of the University clinic for the opportunity to carry out a set of patients and perform the above-mentioned studies.

\section{References}

[1] Aro, P., Ronkainen, J., Storskrubb, T., Bolling-Sternevald, E., Lind, T., Graffner, H. (2003). Quality of life in a general adult population with gastroesophageal reflux symptoms and/or esophagitis. A report from the Kalixanda study. Gastroenterology, 124 (4), 168-169. doi: 10.1016/s0016-5085(03)80835-1

[2] Sobieraj, D. M., Coleman, S. M. (2011). US prevalense of upper gastrointestinal symptoms: a symptomatic literature review. American Journal of Managed Care, 17, 449-458.

[3] Minatsuki, C., Yamamichi, N., Shimamoto, T., Kakimoto, H., Takahashi, Y., Fujishiro, M. et. al. (2013). Background Factors of Reflux Esophagitis and Non-Erosive Reflux Disease: A Cross-Sectional Study of 10,837 Subjects in Japan. PLoS ONE, 8 (7), e69891. doi: 10.1371/journal.pone.0069891

[4] Kwiatek, M. A., Roman, S., Fareeduddin, A., Pandolfino, J. E., Kahrilas, P. J. (2011). An alginate-antacid formulation (Gaviscon Double Action Liquid) can eliminate or displace the postprandial "acid pocket" in symptomatic GERD patients. Alimentary Pharmacology \& Therapeutics, 34 (1), 59-66. doi: 10.1111/j.1365-2036.2011.04678.x

[5] Dent, J., El-Serag, H. B., Wallander, M. A., Johansson, S. (2005). Epidemiology of gastro-oesophageal reflux disease: a systematic review. Gut, 54 (5), 710-717. doi: 10.1136/gut.2004.051821

[6] Bredenoord, A. J., Weusten, B. L. A. M., Timmer, R., Smout, A. J. P. M. (2006). Air Swallowing, Belching, and Reflux in Patients with Gastroesophageal Reflux Disease. The American Journal of Gastroenterology, 101 (8), 1721-1726. doi: 10.1111/j.1572-0241.2006.00687.x

[7] Yaylali, O., Kirac, S., Yilmaz, M., Akin, F., Yuksel, D., Demirkan, N., Akdag, B. (2009). Does Hypothyroidism Affect Gastrointestinal Motility? Gastroenterology Research and Practice, 2009, 1-7. doi: $10.1155 / 2009 / 529802$

[8] Sipponen, P., Vauhkonen, M., Helske, T. et. al. (2005). Low circulating levels of gastrin-17 in patients with Barrett's esophagus. World Journal of Gastroenterology, 11 (38), 5988-5992. doi: 10.3748/wjg. v11.i38.5988

[9] Pustorino, S., Calipari, G., Foti, M. et. al. (2002). Esophageal transit and esophageal motility disorders in patients with nontoxic goiter and recurrent dysphagia. Recenti Progressi in Medicina, 93 (4), 235-239.

[10] Lundell, L. R., Dent, J., Bennett, J. R., Blum, A. L., Armstrong, D., Galmiche, J. P. et. al. (1999). Endoscopic assessment of oesophagitis: clinical and functional correlates and further validation of the Los Angeles classification. Gut, 45 (2), 172-180. doi: 10.1136/gut.45.2.172

[11] Roongruedee, C., Rungsun, R., Pinit, K. (2010). Role of digital chromoendoscopy in detecting minimal change esophageal reflux disease. World Journal of Gastrointestinal Endoscopy, 2 (4), 121-129. doi: 10.4253 wjge.v2.i4.121 
[12] Di Mario, F., Goni, E. (2015). A non-invasive approach to diagnosis of upper gastrointestinal diseases. Milan: AREA QUALITÀ S.r.1, 64.

[13] Donald, O., Castell, M. D. (2013). Laryngopharyngeal Reflux To Be Or Not To Be? Journal of Clinical Gastroenterology, 47 (3), 193-194. doi: 10.1097/mcg.0b013e318279ac07

[14] Igarashi, M., Nagano, J., Tsuda, A., Suzuki, T., Koike, J., Uchida, T. et. al. (2014). Correlation between the Serum Pepsinogen I Level and the Symptom Degree in Proton Pump Inhibitor-Users Administered with a Probiotic. Pharmaceuticals, 7 (7), 754-764. doi: 10.3390/ph7070754

[15] Thomas, E., Wade, A., Crawford, G., Jenner, B., Levinson, N., Wilkinson, J. (2014). Randomised clinical trial: relief of upper gastrointestinal symptoms by an acid pocket-targeting alginate-antacid (Gaviscon Double Action) - a double-blind, placebo-controlled, pilot study in gastro-oesophageal reflux disease. Alimentary Pharmacology \& Therapeutics, 39 (6), 595-602. doi: 10.1111/apt.12640

[16] Hamdan, A.-L., Jabbour, J., Al Zaghal, Z., Azar, S. T. (2012). Goiter and Laryngopharyngeal Reflux. ISRN Endocrinology, 2012, 1-6. doi: 10.5402/2012/208958

[17] Suzuki, H., Masaoha, T., Hoso da, H. et. al. (2006). Plasma ghrelin concentration correlates with the levels of serum pepsinogen $\mathrm{T}$ and pepsinogen I II ratio - a possible novel and noninvasive marker for gastric atrophy. Hepatogastroenterology, 51, 1249-1254.

[18] Agreus, L., Storskrubb, T., Aro, P., Ronkainen, J., Talley, N. J., Sipponen, P. (2009). Clinical use of proton-pump inhibitors but not $\mathrm{H} 2$-blockers or antacid/alginates raises the serum levels of amidated gastrin-17, pepsinogen I and pepsinogen II in a random adult population. Scandinavian Journal of Gastroenterology, 44 (5), 564-570. doi: 10.1080/00365520902745062

[19] Katz, P. O., Gerson, L. B., Vela, M. F. (2013). Guidelines for the Diagnosis and Management of Gastroesophageal Reflux Disease. The American Journal of Gastroenterology, 108 (3), 308-328. doi: 10.1038/ ajg.2012.444

[20] Nwokediuko, S. C. (2012). Current Trends in the Management of Gastroesophageal Reflux Disease: A Review. ISRN Gastroenterology, 2012, 1-11. doi: 10.5402/2012/391631 